\title{
Corrosion Detection of Reinforcement of Building Materials with Piezoelectric Sensors
}

\author{
J. Peng* \\ Department of Materials Engineering, Sichuan College of Architectural Technology, \\ Deyang, Sichuan, 618000, P.R. China
}

\begin{abstract}
|| Abstract
The extensive use of reinforced materials in the construction industry has raised increased concerns about their safety and durability, while corrosion detection of steel materials is becoming increasingly important. For the scientific management, timely repair and health monitoring of construction materials, as well as to ensure construction safety and prevent accidents, this paper investigates corrosion detection on construction materials based on piezoelectric sensors. At present, the commonly used corrosion detection methods include physical and electrochemical methods, but there are shortcomings such as large equipment area, low detection frequency, and complex operation. In this study an improved piezoelectric ultrasonic sensor was designed, which could not only detect the internal defects of buildings while not causing structural damage, but also realize continuous detection and enable qualitative and quantitative assessment. Corrosion detection of reinforced building materials with piezoelectric sensors is quick and accurate, which can find hidden dangers and provide a reliable basis for the safety of the buildings.
\end{abstract}

$\|$ Keywords

Building materials, reinforced concrete, piezoelectric sensor, corrosion detection, ultrasound

\section{Introduction}

Rebar refers to a steel material used in the production of reinforced concrete and prestressed reinforced concrete, which are widely used in a variety of building structures. Due to the influence of ribs and the bonding capacity of concrete, deformed bars can better withstand external forces and are commonly used materials for large, heavy, and high-rise building structures. However, the safety of buildings can be affected by construction quality, environmental erosion, material aging, and other factors. Once a building is affected by these factors, damage will occur, bringing economic loss and security threats. Therefore, it is vital to perform corrosion detection. At present, many experts and scholars have carried out related research. Elbatanouny et al. ${ }^{1}$ performed early corrosion detection in prestressed concrete girders using acoustic emission. Bertolini et al. ${ }^{2}$ introduced the main characteristics of chloride electrochemical behaviour of steel in polluted concrete based on the Tuutti model, described the electrochemical test in alkaline solutions of simulated concrete pore fluids, and discussed the tests of bars embedded in concrete (or mortar) samples. Simmers et al. ${ }^{3}$ conducted detection of corrosion using piezoelectric impedance-based structural health monitoring. The use of piezoelectric ultrasonic sensor for corrosion testing of reinforced concrete, as presented in this paper, can effectively compensate for the lack of traditional detection technologies, realize real-time monitoring of the construction situation, and achieve early damage and corrosion degree assessment with reliability,

* Dr Jia Peng

email: pengjia123@yahoo.com safety and good application values. Compared to the other equipment previously put forward, it enables qualitative and quantitative assessment, as well as continuous detection without causing damage to the architecture.

\section{Theoretical study of corrosion detection}

\subsection{Corrosion of steel bars}

Reinforcement materials are widely used in modern construction because of their low cost and good durability. Reinforced concrete ${ }^{4}$ has high compressive strength and good tensile strength, with good bonding power and similar coefficients of thermal expansion between rebar and concrete, and has gradually become an important part of modern building materials. However, in the course of use, steel corrosion ${ }^{5}$ problems are constantly emerging. When chloride ions and carbon dioxides in the external environment intrude into the steel structure, the passivation film on the surface of the steel will be damaged, and an anode and a cathode will be formed on the surface, which, together with oxygen and moisture, will cause corrosion. Taking chloride ions as an example, once entering the steel material, they would accelerate the corrosion process rather than be consumed. Corrosion causes the cross-section of the steel bars to reduce, which weakens their bearing capacity as well as the bond between the rebar and concrete. Besides, the expansion of the corrosion product's volume will lead to cracks in the surrounding concrete, which will severely affect the durability and suitability of the structure. 


\subsection{Corrosion detection}

Therefore, it is necessary to carry out corrosion detection $^{6}$ to acquire timely corrosion situation of buildings, assess durability and safety of buildings, and take appropriate maintenance measures. Commonly used detection methods include physical and electrochemical methods, but they all have some flaws. Physical methods, such as the resistance method, are applicable only in the detection of severe corrosion of steel bars and cause damage to the structure, while the measurement accuracy is low; the electrochemical method ${ }^{7}$ is a commonly used detection method, which provides quantitative information on the corrosion rate. Therefore, piezoelectric sensors are applied to detect corrosion of steel bars in this study, which can achieve real-time and long-term on-line monitoring of corrosion, determine the location of the damage and the specific stage of corrosion, and provide an effective basis for building safety.

\subsection{Application design of piezoelectric ultrasonic sensor in reinforced concrete}

The designed piezoelectric ultrasonic sensor ${ }^{8}$ is mainly composed of transmitting type piezoelectric ultrasonic sensor and receiving type piezoelectric ultrasonic sensor. The transmitting type piezoelectric ultrasonic sensor takes PZT (lead zirconium titanate) piezoelectric ceramic ${ }^{9}$ as the piezoelectric element and uses modified acrylic adhesive to bond wires and piezoelectric elements. In the design, an acoustic matching layer is added between the sensor and the working medium, which is a composite material composed of cement, epoxy resin, and curing agent, and can effectively reduce the reflection of sound waves and protect piezoelectric components, with a thickness of a quarter that of the acoustic wavelength. A backing layer is added to the rear of the piezoelectric element in order to absorb excess sound waves and enhance the signal energy. The structural design of the receiving type piezoelectric ultrasonic sensor takes cement-based piezoelectric composite material ${ }^{10}$ as the piezoelectric component to receive external acoustic signals, which is basically the same with the transmitting type piezoelectric ultrasonic sensor. Using the sensor to send pulse waves of a certain frequency to the reinforced concrete structure, ultrasonic waves will be affected by the internal corrosion of the reinforced concrete and produce some changes, which can be collected for analysis to obtain the corrosion situation inside the reinforced concrete.

\section{Corrosion detection with piezoelectric sensor}

\subsection{Experimental materials and devices}

\subsubsection{Experimental materials}

The reinforced concrete used in this experiment was provided by Sichuan Deyang Jiatai Cement Products Co., Ltd. The mixing ratio of concrete water : cement : sand : stone was $0.46: 1: 1.87: 3.29$. Here, the G-85 steel was selected. All factors of test block I and test block II are the same, both of which were prepared for use after 30 days of maintenance. The $\mathrm{NaCl}$ solution with a mass fraction of $5 \%$ was used for corrosion treatment.

\subsubsection{Experimental devices}

An ultrasonic detector was applied to collect the ultrasonic signals of the piezoelectric ultrasonic sensor. A waveform generator ${ }^{11}$ (33500B series, Keysight) was applied as a pulse generator to excite the ultrasonic sensor to produce the corresponding ultrasonic pulse wave. A digital oscilloscope $^{12}$ (RTB2000, Rohde \& Schwarz) was used to collect the ultrasonic signal of the sensor and upload it to the computer for further analysis.

\subsection{Experimental methods}

The reinforced concrete test piece I was put into the $\mathrm{NaCl}$ solution, the positive pole of the power source was connected with the wire connecting the reinforcing bar, and the negative electrode was connected with the graphite rod in the solution. The transmitter and receiver sensors pasted at both ends of the bar were connected to the waveform generator and the digital oscilloscope, respectively, while the other channel was connected by wires. The frequency was adjusted to $100 \mathrm{kHz}$, and the transmit electric potential was adjusted to the maximum so that the digital oscilloscope could clearly display the ultrasonic waveforms. The supply potential was $2 \mathrm{~V}$. After the power supply was energized, the test started and the data was collected every hour. When the test piece I had obvious cracks, the test stopped. For a more comprehensive monitoring of the corrosion of steel bars, we carried out a second experiment. Using the ultrasonic velocity to construct the damage variables, the quantitative results of the corrosion of the concrete structure were obtained. The reinforced concrete test block II was immersed in $\mathrm{NaCl}$ solution, onto which the piezoelectric ultrasonic sensor was placed. DC power supply was adopted for current output. The positive electrode was connected with the steel bar, and the negative electrode with the copper rod to generate the current loop. The quality of the specimen was measured before and after the experiment. The damage condition of the concrete was detected by monitoring the change in the sensor signals. Firstly, the ultrasonic signals were collected when the reinforced concrete was in good condition. The reinforced concrete was then damaged by adding the applying load step by step ${ }^{13}$ to collect the acoustic signals at all stages under these conditions. By observing and recording the changing trend in signal parameters received by the sensor during the damage process, the quantitative relationship between the ultrasonic signal and the damage of the reinforced concrete was analysed, and the results confirmed that piezoelectric ultrasonic sensors were feasible and effective for corrosion detection.

\subsection{Experimental results}

As shown in Fig. 1, with the increase in corrosion time, the number of ultrasonic signals also gradually increased. 
At the beginning of the corrosion, the number of signals barely showed an increase. In the $3^{\text {rd }}$ hour of corrosion, the signal number increased at a fast speed, which slowed down during the $4^{\text {th }}$ and $8^{\text {th }}$ hour of corrosion. In the $9^{\text {th }}$ hour of corrosion, the signal number showed a sharp increase, where the rust products reached a certain amount and continued to expand, leading to cracks inside the reinforced concrete and an increased number of ultrasonic signals. This suggested that by analysing the changes in the ultrasonic signal with time, it was possible to obtain the information of the degree and amount of corrosion of the steel material.

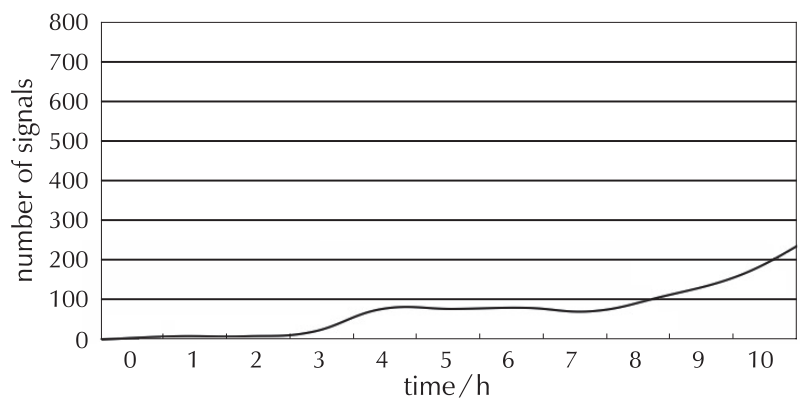

Fig. 1 - Relationship between the time of corrosion and the number of ultrasonic signals

Corrosion of steel will cause cracks in concrete. According to a previous study ${ }^{14}$, when the frequency is greater than $20 \mathrm{kHz}$, the linear elastic isotropic cylindrical ultrasonic wave velocity is:

$$
v_{1}^{2}=\frac{E}{\rho} \frac{1-v}{(1+v)(1-2 v)}
$$

Assuming that the damage is made up of microcracks, the damage degree of the rebar material can be obtained by constructing the damage variable with ultrasonic waves, and the longitudinal wave velocity of the damaged material is:

$$
v_{0}^{2}=\frac{E_{0}}{\rho_{0}} \frac{1-v}{(1+v)(1-2 v)}
$$

Then, the damage degree of reinforcing bar materials can be obtained with the following equation:

$$
D=1-\frac{E_{0}}{E}=1-\frac{\rho_{0}}{\rho} \frac{v_{0}^{2}}{v_{1}^{2}}
$$

where $D$ refers to damage degree, $E$ refers to elastic modulus $^{15}$ under reinforcement material damage conditions, $\rho$ refers to density ${ }^{16}$ under damage conditions, $v$ refers to Poisson's ratio, $v_{1}$ refers to longitudinal ultrasonic wave in an intact test block, and $v_{0}$ refers to longitudinal wave velocity under damage conditions.
As shown in Fig. 2, under different damage degrees, the frequency of the ultrasonic signal received by the piezoelectric ultrasonic sensor in reinforced concrete was different. When the load was not applied, the resonant amplitude of the intact reinforced concrete was increasing, and the received signal had the highest amplitude at $100 \mathrm{kHz}$; when the maximum load $\left(50 \mathrm{~N} \mathrm{~mm}^{-2}\right)$ was applied, cracks appeared on the surface of the reinforced concrete and the amplitude of the resonance reduced by half compared to that before applying the load. Therefore, the damage degree of reinforced concrete can be determined according to the frequency amplitude situation.

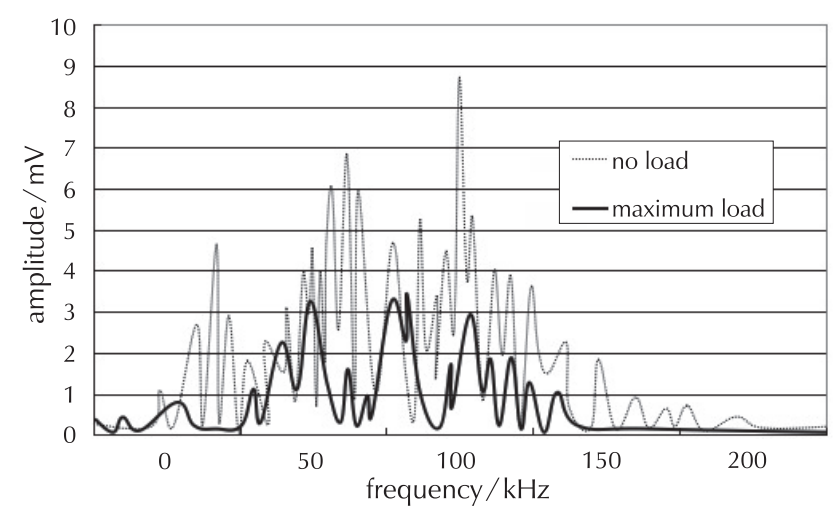

Fig. 2 - Calculation of received signals of piezoelectric ultrasonic sensor in reinforced concrete under different loads

When a current loop is generated and steel corrosion appears, the quality of the steel will decrease to some extent. According to the Faraday theorem, it is found that the amount of corrosion is a function of electric potential, current, and energization time.

Furthermore, the relationship between the quality loss of corroded steel bars and the amplitude growth rate of ultrasonic signals was studied. Quality loss of steel corrosion can be expressed by the following equation:

$$
m=\frac{\bar{I} t M(\mathrm{Fe})}{2 F}
$$

As shown in Fig. 3, there was a correlation between the rate of increase in amplitude and the quality loss of steel bars. With the increase in the quality loss of steel bars, the growth rate of ultrasonic amplitude also increased. The higher the ultrasonic signal amplitude, the greater the value of $D$. When the mass loss reached about $1.5 \mathrm{~g}$, the growth rate tended to slow down, where steel and concrete has completely separated. In the beginning of the corrosion of steel bars, according to the continuous increase in ultrasonic amplitude, the situation of corrosion could be determined. When the steel and concrete had basically separated, the amplitude no longer grew, indicating that the piezoelectric ultrasonic sensor could effectively determine the stage of steel corrosion. 


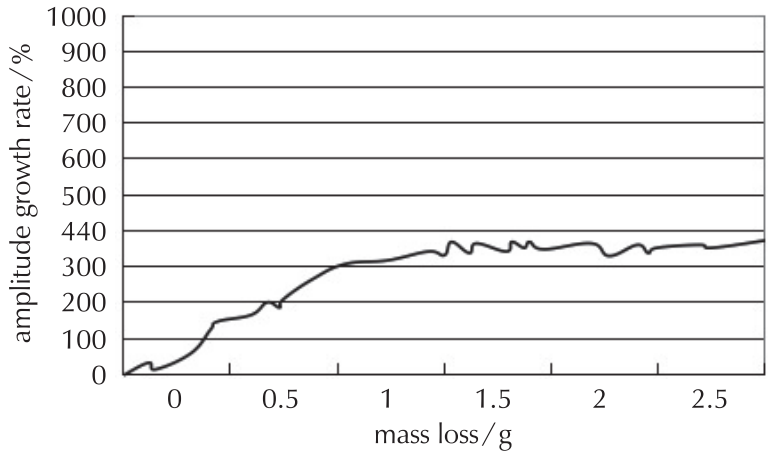

Fig. 3 - Relationship between the mass loss of steel bars and the amplitude growth rate of ultrasonic signals

\section{Conclusion}

This study confirms that by applying the piezoelectric sensor to carry out corrosion detection on reinforcement building materials, the real-time online collection of ultrasonic signals can be realized. According to the signal amplitude changes, the corrosion situation and damage degree of steel materials can be determined in order to make a reliable assessment of the safety of buildings. However, apart from the previously mentioned various advantages, ultrasonic sensors also have some shortcomings, such as single directionality of sending and receiving, which cannot meet the requirement of a more complex corrosion situation in the natural environment. Hence, further studies need to be conducted in the near future.

\section{List of symbols}

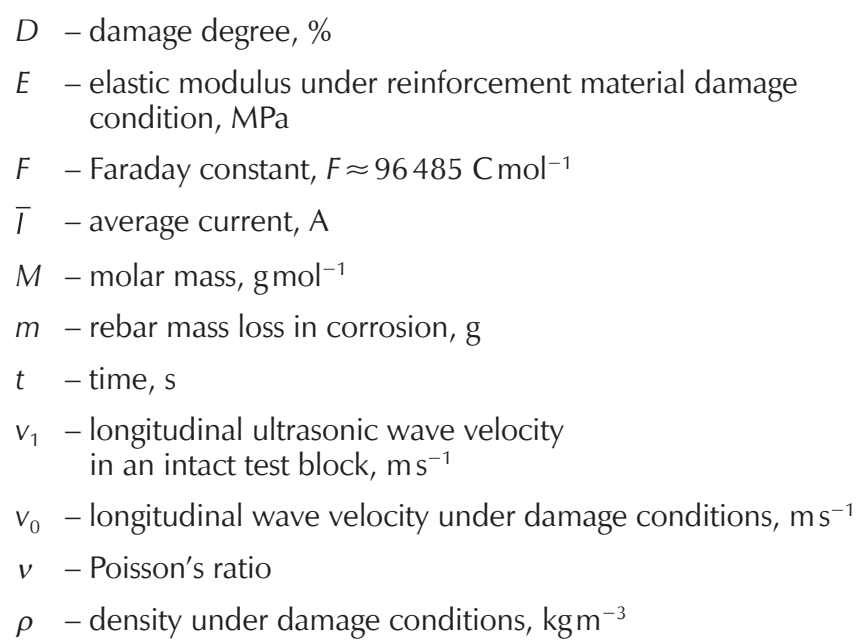

\section{References Literatura}

1. M. K. Elbatanouny, J. Mangual, P. Ziehl, F. Matta, Early Corrosion Detection in Prestressed Concrete Girders Using Acoustic Emission, J. Mater. Civil Eng. 26 (3) (2014) 504-511, doi: https://doi.org/10.1061/(ASCE)MT.1943-5533.0000845.

2. L. Bertolini, E. Redaelli, Depassivation of steel reinforcement in case of pitting corrosion: detection techniques for laboratory studies, Mater. Corros. 60 (8) (2015) 608-616, doi: https://doi.org/10.1002/maco.200905276.

3. G. E. Simmers, H. A. Sodano, G. Park, D. J. Inman, Detection of Corrosion Using Piezoelectric Impedance-Based Structural Health Monitoring, Aiaa J. 44 (11) (2015) 2800-2803, doi: https://doi.org/10.2514/1.24273.

4. W. H Dilger, Reinforced concrete: mechanics and design, Can. J. Civil Eng. 27 (6) (2000) 1316, doi: https://doi. org/10.1139/I00-087.

5. Z.-Y. Ai, W. Sun, J.-Y. Jiang, Recent Status of Research on Corrosion of Low Alloy Corrosion Resistant Steel and Analysis on Existing Problems, Corros. Sci. Prot. Technol. 27 (6) (2015) 525-536, doi: https://doi.org/10.11903/1002.6495.2014.4 07.

6. T. Watanabe, H. T. Huyen Trang, K. Harada, C. Hashimoto, Evaluation of Corrosion-induced Crack and Rebar Corrosion by Ultrasonic Testing, Const. Build. Mater. 67 (2014) 197-201, doi: https://doi.org/10.1016/j.conbuildmat.2014.05.013.

7. B. Bhuvaneshwari, A. Selvaraj, N. R. Lyer, L. Ravikumar, Electrochemical Investigations on the Performance of Newly Synthesized Azomethine Polyester on Rebar Corrosion, Mater. Corros. 66 (4) (2015) 387-395, doi: https:// doi.org/10.1002/maco.201307472.

8. W. Hwang, H. C. Park, Finite element modeling of piezoelectric sensors and actuators, AIAA J. 31 (31) (2015) 930-937, doi: https://arc.aiaa.org/doi/10.2514/3.11707.

9. Ma. S. da Silva, L. L. Silva, E. F. Souza, E. Longo, M. A. Zaghete, A. A. Cavalheiro, Study on the Piezoelectric Behavior and Structural Changes of Strontium Doped PZT Ceramics, $21^{\text {st }}$ Brazilian Conference on Materials Science and Engineering 869 (2016) 13-18, doi: https://doi.org/10.4028/www. scientific.net/MSF.869.13.

10. M. Z. Yuan, J. R. Zhang, L. Z. Yang, E. Q. Fang, Z. J. Li, H. Ren, Processing method and property study for cement-based piezoelectric composites and sensors, Mater. Res. Innov. 19 (4) (2015) 138-142, doi: https://doi.org/10.1179/143289 1715Z.0000000001389.

11. A. Depari, M. Lavarini, A. Flammini, E. Sisinni, Performance of all-digital waveform generators for narrowband power line communications, IEEE International Instrumentation and Measurement Technology Conference Proceedings, 2016, pp. 1-6, doi: https://doi.org/10.1109/ I2MTC.2016.7520416.

12. J. Jiang, S. L. Tian, A Method of Improving Signal Capture Ability of Digital Oscilloscope, Adv. Mater. Res. 721 
(2013) 392-396, doi: https://doi.org/10.4028/www.scientific.net/AMR.721.392.

13. J. M. C. Ongpeng, W. C. Oreta, S. Hirose, Effect of Load Pattern in the Generation of Higher Harmonic Amplitude in Concrete Using Nonlinear Ultrasonic Test, J. Adv. Concr. Technol. 14 (5) (2016) 205-214, doi: https://doi. org/10.3151/jact.14.205.

14. Y. Shin, Y. H. Yoon, Y. H. Kim, Measurement of Longitudinal and Transverse Wave Speed in Solid Materials Using Immersion Ultrasonic Testing (in Korean), J. Korean Soc. Nonde- struc. Test. 28 (1) (2008) 40-45.

15. M. Destrade, R. W. Ogden, On Stress-Dependent Elastic Moduli and Wave Speeds, J. Appl. Mathem. 78 (5) (2013) 965-997, doi: https://doi.org/10.1093/imamat/hxs003.

16. R. P. Kumar, T. Oshima, S. Mikami, Y. Miyamori, T. Yamazaki, Damage Identification in a Lightly Reinforced Concrete Beam Based on Changes in the Power Spectral Density, Struct. Infrastr. Eng. 8 (8) (2012) 715-727, doi: https:// doi.org/10.1080/15732471003730674.

\section{SAŽETAK \\ Detekcija korozije armature građevnog materijala piezoelektričnim senzorom \\ Jia Peng}

Široka upotreba armiranih materijala u građevinarstvu povećava brigu oko njihove sigurnosti i trajnosti, a raste važnost detekcije korozije čelika. Istražena je detekcija korozije građevnih materijala piezoelektričnim senzorima radi kontrole stanja, pravodobne obnove, sigurnosti i sprječavanja nesreća. Sada se najčešće primjenjuju fizikalne i elektrokemijske metode, nedostatci kojih su složenost, glomazna oprema te niska učestalost detekcije.

$\cup$ ovom je istraživanju osmišljen piezoloektrični ultrazvučni senzor kojim se mogu nedestruktivno otkriti unutarnji defekti građevinskih konstrukcija, a također omogućuje kontinuirano kvalitativno i kvantitativno praćenje stanja. Detekcija korozije armiranih građevnih materijala piezoelektričnim senzorima brza je i precizna te se njome mogu otkriti skrivene opasnosti te pruža pouzdanu osnovu za provjeru sigurnosti građevina.

\section{Ključne riječi}

Građevni materijali, armirani beton, piezolektrični senzor, otkrivanje korozije, ultrazvuk

Department of Materials Engineering

Sichuan College of Architectural Technology

Deyang

Sichuan 618000

Kina
Izvorni znanstveni rad

Prispjelo 22. ožujka 2017. Prihvaćeno 21. svibnja 2017. 